\title{
The Crisis, Responsibility and Regulation
}

\author{
Böhm Arnošt, Fujerová Irena \\ Technical University of Liberec, Liberec, Czech Republic
}

\begin{abstract}
Any observer of current economic development in the world and in the Europe should ask about the causes of the current crisis situation. The authors of this article perceive current situation in the European Union and many of its member states associated with long-term developmental tendencies still less respecting the objective differences in various economic situation of the member states. Establishment and further functioning of monetary union in Europe is gradually becoming a burden for many countries, which prevents full utilization of instruments of monetary and fiscal policy by daily, and in many cases qualitative differences in the problems of economies of individual member states. The fulfillment of these tendencies in particular in the Euro Area monetary policy is confronted with the dominant position of member states in fiscal policy and in the mutual differences among member states. As considerations of differences in economic level and in member states fiscal policies, both of them are based on official figures, some of them are part of the state. In addition, EU institutions face to face to crisis they are increasingly resorting to deepening statist centralization and enter more often to the processes which are usually domains of business subjects, at most of nation states. All these trends lead to a deepening asymmetry between the decision-making processes and responsibilities for economic development and they could lead to even larger failure of national economies or at European or global level. Since the accession of the Czech Republic to the European Union in 2004 our department has dealing with issues connecting to the economic management of insurance companies and in relation to the ongoing integration process research interest is extended also to other segments of financial markets.
\end{abstract}

Keywords: European Union, monetary and fiscal policy, responsibility, regulation

\section{Introduction}

The whole history of today's European Union, as shown below, is influenced by efforts to liberalize trade and approach to business opportunities, building new institutional and legal structures which through its regulatory mechanisms can indirectly limited the business activities. On the other hand the history is influenced by developing different systems and institutions that belong to any of the other stages of development of European integration. At the same time in the EU member states (not in the EU as a whole) there are active different systems of state support to develop the entrepreneurial activities and mainly to cover social and health needs of the population.

Böhm Arnošt, Associate Professor, Head of Department of Insurance Management, Technical University of Liberec. Fujerová Irena, Ph.D. candidate, Department of Insurance Management, Technical University of Liberec.

Correspondence concerning this article should be addressed to Böhm Arnošt, Technical University of Liberec, Faculty of Economics, Studentská 2,46017 Liberec, Czech Republic. E-mail: arnost.bohm@tul.cz. 
At first sight it might seem the "coexistence" of different tendencies as contradictory. On the one hand measures are focused on the development of free trade and next to that there are the state mechanisms aimed at promoting something. Is it really so? Let's look at the problem of those aspects, relevant to the assessment of our questions.

The European Union, especially in the last 10 to 15 years, has passed several generally accepted stages of integration process. From the original concept of "free trade zone", "Customs Union" and "Common Market" (different forms promoting international trade between member states) there was gradually (and quiet quickly) appeared a tendency leading to the formation of Economic and Monetary Union. At this time it is leading even to a full economic and political integration of EU countries to a "Superstate" known as the new European Union.

Based on statistical data and evaluation of current practice in $\mathrm{EU}$, as the authors of this article specify in other paper (Böhm \& Fujerová, 2011), is the main reason the disproportionate and artificial acceleration of the integration process. The integration process is based practically only on one requirement of a common currency but it is not respected and filled by all members. Most of other expected attributes are missing for now. It cannot be surprising! For individual member states are not acceptable further, in addition systemically (i.e., by European legislation) performed reallocation of financial resources between countries based on the unidentifiable ideas of European institutions.

\section{Causes of the Crisis}

Many "fans" among politicians and economists have already considered the financial and political crisis as overcome but the development of the current stage has provided a serious argument to the proponents of conservative approach of European integration process.

From the beginning of the crisis in 2008, there have been issued by the European Central Bank and the International Monetary Fund hundreds of billions Euros for the recovering the crisis. As a result, there mentioned some news about the possible need for recapitalization of the ECB (Bydžovská, 2011).

However, systemically more important is that individual member states are aware of their competences in particular in field of accounting and taxation, and focusing of their expenditure side is governed by the needs of national economies. They support individual segments of the economies in accordance with the traditions, structure, and development plans of the country. This happens in situation where are made, face to face the crises, demands of European institutions for previous negotiation of national budgets of member states.

To cope with the crisis, there formed a number of suggestions different types and orientation. From the European perspective, it can be considered as the most important The Larosière Report (2009) which became the incentive to the tightening the regulation of financial markets and financial services.

Larosière report itself points to the resource problems of the financial sector and suggests possible solutions from the initial stage of the crisis.

A report states in the introduction that governments and central banks around the world have accepted many measures to try to improve the economic situation and reduce systemic risk:

- Economic incentive packages of various forms;

- Huge liquidity packages provided by central banks;

- Recapitalization of financial institutions; 
- To provide guarantees for some types of financial activities;

- And especially interbank lending or direct purchase of assets while the desired result didn't come (not by accidence).

In addition, the report identifies the causes of the crisis which consist mainly in:

- Lack of risk management, consisting mainly in overestimation of the ability of financial firms as a whole to manage their risks and keep adequate capital;

- Lack of credibility of the results of evaluations carried out by rating agencies as a result of not only their subjective lack of preparedness but also with respect to an objective lack of historical data and time series especially on new financial instruments;

- Failure of management and administration of companies stemming primarily from the fact that members of senior management of many financial firms did not understand the properties of new, very complex financial products and the risks associated with them;

- Failure of regulation, supervision and crisis management because just regulated financial institutions have proved to be the largest source of the problem.

If we compare previously applied and mentioned procedures to identify the causes of the crisis we will find a certain inconsistency and we will ask for example:

- Why was it spend and why it spend so huge amount of money to deal with the consequences of failure of risk management of firms, their management and also bad in some cases corrupt the functioning of credit rating agencies?

- Why the fault attributed to poor regulation and supervision, and how does it related to crisis management?

These are entirely warranted considerations. Where is the fault? After all, every country has laws on bankruptcy and settlement, each country has the obligation to include in their legislation all directives and other legal acts of the EU including those relating to the license system, regulation and control of financial institutions activities. So, is there something wrong or dysfunctional in the management of companies or in the specified regulatory system?

Why there issued so huge amounts of money? Could it be used for the payment of system fault or for a lack of courage of responsible people?

This obviously brings us to the core of the problem which is the asymmetry of decision-making process and responsibility for its consequences.

Probably no one doubts about the responsibility of company managers for their proper operation and for the damages caused to their clients or customers with actions or inaction of these managers. Probably no one doubts also about the responsibility of member states, their Central Banks and relevant government institutions for the state of public finances. They are the only ones in Europe and elsewhere in the world which are responsible for the state of public finances. This couldn't be justified by any noble goals or proclamation allowing to citizens some benefits from public funds. So the crisis began in the U.S.- mortgages, mandatory health insurance... Of course, the whole progress is aimed at the same, respectively how people meet more and more satisfaction from their needs in accordance with available resources.

One can then put questions regarding to the responsibility for debts establishment:

- How is it possible that for the poor management and bad investments of financial institutions aren't 
responsible people whose abilities and integrity are investigated in line with EU legislation just before licensing the bank or insurance activities?

- How might be such a huge concentration of investments only in one investment opportunities? For that there are existed EU regulations setting the maximum possible amount to invest in one investment title;

- Is such legislation then effective? Legislation which is compulsorily implemented into the legal system of each country.

Probably not, when debt is increasing in most European countries and the cost of debt service is continuously increasing.

It is remarkable that the European Commission in response to the financial crisis committed in its communication "Speed up Recovery of European Economies" to improve corporate governance in financial institutions (which may perhaps have only promising character!). Commission wanted to ensure greater consideration of the interests of consumers and other stakeholders, sustainable management and reduce the risk of decline in the long run. Furthermore and not in last place there were questions like:

- How to improve the functioning and structure of boards of financial institutions to strengthen their supervisor of senior management;

- How to create a culture of risk management at all levels of financial institutions to ensure reflecting their long-term interests of the company;

- How to strengthen the involvement of shareholders, financial supervisors and external auditors into corporate governance issues;

- How to change the rewarding policy in companies in order to avoid excessive risk-taking.

Permanent solution probably is not even in the artificial maintenance of non-functional structures and rules of their functioning and their further subsidies but in a more fundamental process, i.e., from a strict defined resource problems. So it is probably not useful to expand and tighten pan-European respectively global system of regulation and supervision of financial markets. It certainly does not guarantee a solution appropriate to the situation in concrete country but rather it could harm the users of financial services in the country. As a good example is the obvious requirement emerging in the EU institutions monitoring the increase in share capital of insurance companies. Of course, this appeal might be adequate to insurers in some countries but in any case it would mean for the final consumer, i.e., the policyholder, significantly more expensive insurance.

The failures of regulatory and supervisory mechanisms were not adequate prevention for the European institutions and they are still concentrating their efforts to create another new one but more rigid schemes.

\section{Proposals of the Crisis Management, Again, a New Institution}

For creating a single market of financial services are engaged a relatively wide range of committees and commissions at European level. These committees are primarily on third-level Lamfalussy process ${ }^{1}$ as for example CESR (Capital Market Regulation), CEBS (Banking supervision), CEIOPS (Supervision of Insurance

\footnotetext{
${ }^{1}$ In July 2000, based on decision of The Council of EU was created a working group chaired by Baron Alexandre Lamfalussy. The main goal was to prepare an analysis of regulation mechanisms of capital markets and suggest then the possibility of their adaptation to the conditions on global financial markets. The result of the work of this group was a proposal of four degrees mechanism of acceptance, approval and monitoring of implementation of regulatory requirements for capital markets at EU level which is being called Lamfalussy process.
} 
Companies and Pension Funds) and JCFC (Financial Conglomerates). At the international level, there are institutions like the IOSCO (Capital Market Regulation), IAIS (Insurance Supervision) and IOPS (Supervision of Pension Funds). These activities also participated the Basel Committee on Banking Supervision.

It must be held that the performance of the European Commission and member states is endless especially by the establishment and subsequent reorganization of the various institutions and international organizations (whose mission is to ensure the effectiveness of financial supervision in the EU).

The current financial crisis, according to the Commission also revealed systemic weaknesses of the European supervisory framework. This framework even after a single internal market in this area remains fragmented at national level. The Commission pointed out also the important role of mutual coordination between member states and the legitimate mission pan-European institutions appearing in this area.

The new system, which came into force on 1 January 2011, has been minimized according to the Commission lack of prudential supervision at the macro and micro levels, and it should significantly modify the existing control mechanism. The existing three advisory committees were transformed into multinational sector supervisors.

The existing Committee of European Banking Supervisors (CEBS) has been replaced by the European Banking Authority (EBA), The Committee of European Insurance and Occupational Pensions Supervisors (CEIOPS) has changed into the European Insurance and Occupational Pensions Authority (EIOPA) and from the Committee of European Securities Regulators (CESR), there established European securities Authority and Markets Authority (ESMA). These new sectoral supervisors represent the ESA-European Supervisory Authorities.

The newly constituted authorities took over all the duties of existing institutions, and in addition their responsibilities are expanded on some special competences including:

- Preparation of proposals of the technical standards according to the principles of better regulation;

- Resolving conflicts between supervisors from different member states where they should cooperate under the rules or come to a consensus;

- Helping to ensure uniform application of technical regulations of Union including the implementation of comparative evaluation;

- In the case of performance of ESMA direct supervision of credit rating agencies;

- The role of coordinator in special situations.

Furthermore there constituted two completely new financial supervisory authorities, namely the European Systemic Risk Board (ESRB) and the European System of Financial Supervisors (ESFS). While the ESRB has to deal with the prudential supervision of the financial sector from a macroeconomic perspective, the ESFS supervises the microeconomic level.

European Systemic Risk Board (ESRB) monitors and assesses the risks to the stability of the financial system as a whole (Macro-prudential supervision); provides early warning of systemic risks that could grow and if it is necessary, and makes recommendations how to deal with them into the functioning of ESRB. There are involved activities of leading the European Central Bank, national central banks, the three new European supervisory authorities and national supervisors. The establishment of the ESRB is in line with several initiatives at the multilateral level and outside the EU, including the foundation of the financial stability of the G-20. 
European System of Financial Supervisors (ESFS) performs supervision of individual financial institutions (Micro prudential supervision) which is consists of a network of financial supervisory authorities of member states to cooperate with the new European supervisory authorities. To take account the sectoral differences between different institutions like banking, insurance and occupational pension insurance and securities there was a need to issue three separate directives.

\section{Better and Worse Solutions}

So, it seems that the European institutions remain in belief that institutional changes, especially towards the gradation of the structure of various commissions and advisory authorities are the best cure that will help to overcome the crisis development and to improve predictions of threats other similar failures in the future. Meanwhile, the EU and the Euro area in particular issue still more and more money to "rescue" the Greek, the Portuguese and other economies.

In our opinion, both of these processes are some of the worst. Institutional changes will not solve so much. It should be used more responsibility and professionalism as it can be seen for example in the assessment of territorial and commercial risks in the insurance of export credits and foreign investment in the CONSENS of OECD (2011) and in the International Association of Credit and Investment Insurers called the Berne Union (Berne Union, 2009). Procedures for identification of credit and investment risk of individual countries including his degree of classification are not designed only to justify risk categories of the countries. But they show with the maximum objectivity credibility assessed entities to insurance, financing banks and exporters and investors. The main reason for that is the review based on fixed rules and criteria by participation of experts of all insurance companies represented in the arrangement CONSENSUS. Such reviews include economic, financial and credit characteristics as well as political risk. It includes such variables as GDP, debt service, inflation, dynamics and structure of the economy etc., information that every trader or investor should probably get before contract ${ }^{2}$. Moreover, most of the information and data come from the databases of the International Monetary Fund and World Bank which are from this point of view regarded as priority reference materials.

From this point of view, it is interesting that as the biggest originators of the current situation, not only about de Larosière report, are identified the rating agencies. Yes, definitely they are particularly blamed but what creditors and debtors? They blindly believe them? Neither the European Commission nor other European authorities did know before the crisis how were made the ratings? Definitely, they knew it and announced the principles as early as in 2006 but failed to ensure compliance ${ }^{3}$. It is true with regard to the now publicly mentioned responsibility of rating agencies that they must work more objectively not due to the demands of European institutions but because of its further existence.

And so it is also with managers, crisis managers and others who are responsible at the corporate level for the running of their businesses. That brings again no decisions, recommendations, directives but the simple existential need for managers and their companies. In this context, the questions raised from the de Larosière

\footnotetext{
${ }^{2}$ In CONSENSUS mechanism there are all developed countries with the highest GDP/capita, i.e., all EU countries and other developed countries where are not expected any territorial risks. Credit insurance is going so without state support and on a commercial basis. However this insurance is not provided also without adequate analysis of the creditworthiness of customers and conditions provided by economic and political situation in its country headquarters.

3 The statement of The Commission about the Rating Agencies 2006/C 59/02), Official Journal of EU.
} 
report concerning to the strengthening of management board, the greater involvement of shareholders in corporate governance and executive managers compensation and also in the context of strengthening supervisory competences are almost irrelevant. Hopefully, the reason for that is not creating any instances (national or even European) which is not participating on the business capital determined to shareholders what, how and when they should do, with how many people and with such salaries. These attempts are currently emerging (mainly about the salaries and rewards of managers of large financial institutions) but hopefully (again) this is just a political proclamation aimed at voters and not economic reality.

The role and responsibility of state and European institutions lies in creating especially information and legislative conditions for companies business in the EU for improving the internal market while the European Commission can implement its proposals only indirectly, i.e., through national legislation. This is even so in situation where the 17 member states elected as its currency the euro and in that case overtook their responsibility for monetary policy the European Central Bank.

\section{Dichotomy of Monetary and Fiscal Policy in the EU}

The information stated above brings us to the most important problem in the present stage of European integration. It's about finding the optimal relation between monetary and fiscal policy as two major macro-policies. One of them is proposed and implemented by the European Central Bank - the monetary policy (at least the countries of the Eurozone), and the other fiscal policy are proposed through national governments. These two key "Macro Policies" may be complementary or reduce their interaction or may be in the position of the dominant policy and it subordinates. These and certainly many other reasons have to be very well thought out by making economic mix, especially if the two policies are determined by mutually independent institutions (Prušvic, 2007).

In this context, it is necessary to mention the facts accompanying the current stage of the development of EMU, i.e., the assumptions and limits the functioning of the single currency in relation to relatively but objectively atomized fiscal policies of EU countries, respectively Euro-zone.

Condition for accepting the euro is the fulfillment of the convergence criteria, including:

(1) Price stability - the member state must have sustainable price stability and an average rate of inflation, observed over a period of one year before the measurement which shall be not exceed by more than 1.5 percentage points of inflation by more than three best performing member states.

(2) Long-term interest rates — over one year before the measurement, the average nominal long-term interest rate shall be not exceed by more than 2 percentage points of three best performing member states in terms of price stability;

(3) Long-term sustainability of public finances;

- The Annual government deficit: the ratio of expected or actual government deficit to Gross Domestic Product (GDP) at market prices must not exceed 3\%.

- Government Debt: the ratio of gross government debt at market prices to GDP must not exceed 60\%.

(4) Exchange stability rate and participation in the ERM (exchange rate mechanism)-Member state must comply limits that are determined by Exchange Rate Mechanism of European Monetary System without significant deviation during at least the last two years before investigation. Particularly in this period, the bilateral 
exchange rates of the domestic currency can't depreciate to the currency of any other member state (and to the euro after the introduction);

(6) Convergence in the legislative area contains a condition of independence of central banks, including prohibition the funding of public institutions from the resources of central banks and the prohibition of privileged access to sources of credit institutions. ${ }^{4}$

If we look at the reality from 2010 we will find many states, not just those "famous", which does not meet the long-term criteria (and in some of Euro area members is the question whether they are ever filled). How succeeded the EU countries and especially the Euro area countries are in meeting the criteria for long-term sustainability of public finances shows in Tables 1-3 (Česká Spořitelna a.s., 2006).

Table 1

Government Debt to GDP (Criterion 60\%)

\begin{tabular}{lllllllllll}
\hline & 2002 & 2003 & 2004 & 2005 & 2006 & 2007 & 2008 & 2009 & 2010 \\
\hline EU $^{*}$ & 60.4 & 61.9 & 62.2 & 62.8 & 61.5 & 58.8 & 62.3 & 74.4 & 80.0 \\
EMU & 68.0 & 69.1 & 69.5 & 70.1 & 68.5 & 66.2 & 69.8 & 66.2 & 69.9 & \\
\hline
\end{tabular}

Notes. ${ }^{*}$ European Union in total (EU12-1994, EU15-2004, EU25-2006, EU27). Source: EU Statistics (2011).

Table 2

Deficit/Surplus of Public Budgets to GDP (Criterion 3\%)

\begin{tabular}{llllllllll}
\hline & 2002 & 2003 & 2004 & 2005 & 2006 & 2007 & 2008 & 2009 & 2010 \\
\hline EU $^{*}$ & -2.5 & -3.1 & -2.9 & -2.5 & -1.5 & -0.9 & -2.4 & -6.8 & -6.4 \\
EMU & -2.6 & -3.1 & -2.9 & -2.5 & -1.4 & -0.7 & -2.0 & -6.3 & -6.0 \\
\hline
\end{tabular}

Notes. ${ }^{*}$ European Union in total (EU12-1994, EU15-2004, EU25-2006, EU27). Source: EU Statistics (2011).

Table 3

Annual Average Inflation Rate

\begin{tabular}{lllllllllll}
\hline & 2002 & 2003 & 2004 & 2005 & 2006 & 2007 & 2008 & 2009 & 2010 \\
\hline EU $^{*}$ & 2.1 & 2.0 & 2.0 & 2.2 & 2.2 & 2.3 & 3.7 & 1.0 & 2.1 \\
EMU & 2.3 & 2.1 & 2.2 & 2.2 & 2.2 & 2.1 & 3.3 & 0.3 & 1.6 & \\
\hline
\end{tabular}

Notes. ${ }^{*}$ European Union in total (EU12-1994, EU15-2004, EU25-2006, EU27). Source: EU Statistics (2011).

All these data show long term deficits dominating in the European Union and in the Eurozone. Practically in all member states there are applied such deficits in varying degrees, in a situation where is not set a uniform tax system and the differences in direct and indirect taxes (as main income of public budgets) are significant, as illustrates the following table from 2010 (see Table 4) (Financial Portal Finance, 2011).

As it is apparent, there is inconsistency in this area in terms of tax rates and in tax structure. This situation is not characteristic only for the all EU countries but there are the same differences between Euro area countries as well. The case of this situation is "That the member states do not give up their habits in favor of a common market and they consider interventions in standard rates and rates of income taxes as interference in their own affairs so that harmonization is a political problem" (Kubátová, 2003). In a crisis situation ongoing now in EU, there is forcing once again the differential interference of tax systems with the goal rather than to not to optimize the tax

4 The Treaty on European Union (92/C 191/1). Retrieved August 16, 2011, from http://www.euroskop.cz. 
system but more to avoid the collapse of public finances.

Table 4

Overview of Standard and Reduced Rates of VAT and Individual Income Tax and Corporate Income Tax in the European Union Forced in $2010^{1}$

\begin{tabular}{|c|c|c|c|c|}
\hline & Standard rate of VAT & Reduced rate of VAT & Individual income tax & Corporate income tax \\
\hline Belgium & 21 & $6 / 12$ & 50 & 33 \\
\hline Bulgaria & 20 & 7 & 10 & 10 \\
\hline Czech Republic & 20 & 10 & 15 & 19 \\
\hline Denmark & 25 & - & 51 & 25 \\
\hline Estonia & 20 & 9 & 21 & 21 \\
\hline Finland & 23 & $9 / 13$ & 30 & 26 \\
\hline France & 19.6 & $2.1 / 5.5$ & 40 & 33.33 \\
\hline Ireland & 21 & $4.8 / 13.5$ & 41 & 12.5 \\
\hline Italy & 20 & $4 / 10$ & 43 & 27.5 \\
\hline Cyprus & 15 & $5 / 8$ & 30 & 10 \\
\hline Lithuania & 21 & $5 / 9$ & 20 & 15 \\
\hline Latvia & 21 & 10 & 26 & 15 \\
\hline Luxembourg & 15 & $3 / 6 / 12$ & 38 & 21 \\
\hline Hungary & 25 & 5 & 32 & 19 \\
\hline Malta & 18 & 5 & 35 & 35 \\
\hline Germany & 19 & 7 & 45 & 15 \\
\hline Netherlands & 19 & 6 & 52 & 25.5 \\
\hline Poland & 22 & $3 / 7$ & 32 & 19 \\
\hline Portugal & 20 & $5 / 12$ & 42 & 25 \\
\hline Austria & 20 & $10 / 12$ & 50 & 25 \\
\hline Romania & 19 & 9 & 16 & 16 \\
\hline Greece & 19 & $4.5 / 9$ & 40 & 25 \\
\hline Slovakia & 19 & 10 & 19 & 19 \\
\hline Slovenia & 20 & 8.5 & 41 & 20 \\
\hline Spain & 16 & $4 / 7$ & 45 & 30 \\
\hline Sweden & 25 & $6 / 12$ & 25 & 26.3 \\
\hline Great Britain & 17.5 & 5 & 40 & 28 \\
\hline
\end{tabular}

If we mentioned the need for an appropriate mix of monetary and fiscal policies to ensure the functioning of monetary union then we find that as a very distant goal. Functioning of EMU will be always exposed to all the turbulence of the world economy but also the imbalance situations in the member states which their economies have in more differentiated level, as we pointed out in the text for Liberec Economic Forum 2011 (see Figure 1).

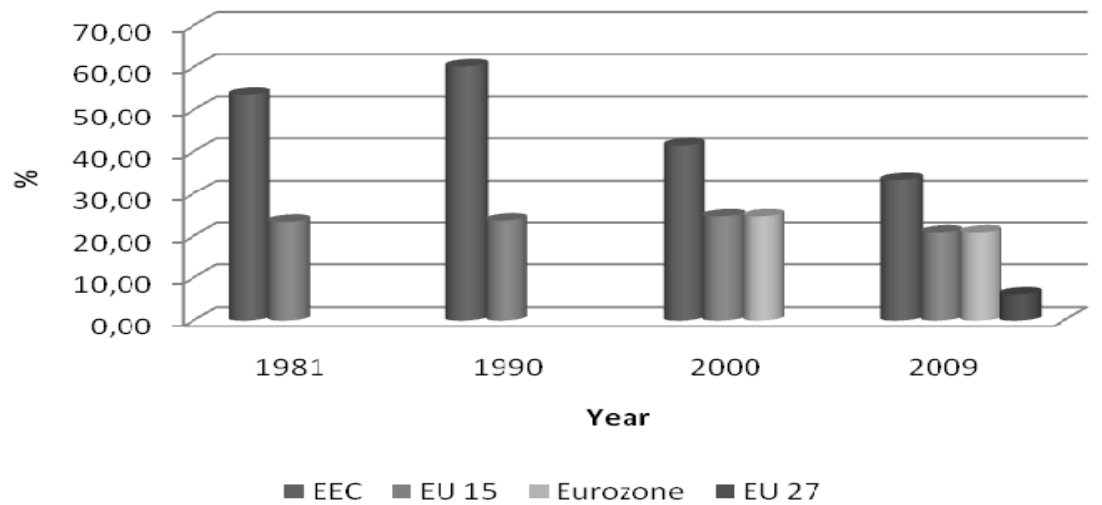

Figure 1. Percentage differences in these groups between the weakest and most powerful EU states. GDP per Capita in PPS about Eurostat, own processing. 


\section{Solution-Revenues and Expenditures of Budgets}

Current problems in EU countries are the result of past policies within individual member states and also in accepted and approximately 20 years promoted developmental stage of economies and their interrelationships inadequate to the acceleration of economic integration.

One of the major problems is degree of concentration of resources and their distribution within individual EU member states where states / governments dispose almost with $45 \%$ of Gross Domestic Product (see Table 5), while their expenditures exceed this limit (see Table 6).

Government revenue and expenditure in EU member states (in \% GDP) (EU Statistics, 2010).

Table 5

Government Revenue (in \% GDP)

\begin{tabular}{lllllllllll}
\hline & 2002 & 2003 & 2004 & 2005 & 2006 & 2007 & 2008 & 2009 & 2010 \\
\hline EU in total & 44.1 & 44.1 & 43.9 & 44.4 & 44.8 & 44.8 & 44.8 & 44.0 & 44.0 \\
Euro area & 44.9 & 44.9 & 44.5 & 44.8 & 45.3 & 45.3 & 44.9 & 44.5 & 44.5 & \\
\hline
\end{tabular}

Table 6

Government Expenditure (in \% GDP)

\begin{tabular}{lllllllllll}
\hline & 2002 & 2003 & 2004 & 2005 & 2006 & 2007 & 2008 & 2009 & 2010 \\
\hline EU in total & 46.7 & 47.2 & 46.8 & 46.8 & 46.3 & 45.6 & 46.9 & 50.8 & 50.3 \\
Euro area & 47.6 & 48.0 & 47.5 & 47.3 & 46.7 & 46.0 & 47.0 & 50.8 & 50.5 \\
\hline
\end{tabular}

Share of total government expenditure to Gross Domestic Product is different in different countries in 2010 (see Table 7) (EU Statistics, 2010).

Table 7

Share of Government Expenditure to GDP in the EU Countries (in \% of GDP)

\begin{tabular}{llll}
\hline GEO/TIME & 2010 & GEO/TIME & 2010 \\
\hline European Union (27 countries) & 50.3 & Germany & 46.6 \\
European Union (25 countries) & 50.4 & Cyprus & 46.6 \\
European Union (15 countries) & 50.8 & Hungary & 48.9 \\
Euro area (17 countries) & 50.5 & Slovenia & 49.0 \\
Euro area (16 countries) & 50.5 & Greece & 49.5 \\
Bulgaria & 37.7 & Iceland & 50.0 \\
Estonia & 40.0 & Italy & 50.3 \\
Romania & 40.8 & United Kingdom & 50.6 \\
Slovakia & 41.0 & Portugal & 50.7 \\
Luxembourg & 41.2 & Netherlands & 51.2 \\
Lithuania & 41.3 & Austria & 53.0 \\
Malta & 42.3 & Sweden & 53.0 \\
Latvia & 42.9 & Belgium & 53.1 \\
Spain & 45.0 & Finland & 55.1 \\
Czech Republic & 45.2 & France & 56.2 \\
Poland & 45.7 & Denmark & 58.4 \\
Norway & 45.9 & Ireland & 67.0 \\
\hline
\end{tabular}

In a situation where is a substantial amount of these expenditures mandatory and not only in terms of laws of 
the country but also in terms of compliance with internationally agreed commitments (defense, environment, social protection, etc.) is their reduction fundamental but very difficult economic and mainly a political goal. Reducing expenditures in the individual areas of state budget meets opposition from various political, labor and interest groups with their requirements, often in mutually antagonistic positions. The tension is strengthened with more exogenous factors which further restrict the governments negotiating space. Increasingly so happens that governments follow the heavily asserted but with political losses supported spending cuts instead of the ability offer to the society a new consensus on the form of government participation in economic life.

Current activities aimed at eliminating threats caused by the ongoing financial, economic and debt crisis are as a further incentive to the international redistribution of resources as it is shown in the current practice of the European Union.

In order to protect the financial stability of the European Monetary Union, there established for three years on 9 May 2010 by 16 member states of the Euro area the European Financial Stability Facility (EFSF). Its sources are provided to temporary financial support to those Euro area members that will get into some financial trouble. EFSF can provide liquidity only after request of the Euro area member state. There signed arrangement with the European Commission and the International Monetary Fund on the form of the stabilization program. The program has to be unanimously approved by Euro area finance ministers (the Eurogroup). Providing such aid is tied to the performance of demanding conditions known as conditionality, described in a document Memorandum of Understanding. The parts of agreement on financial aid are also an interest conditions under which aid is provided. The addressees of such support can be only Euro area members. EFSF has only temporary duration. The EU member states agreed in December 2010 need to create a permanent mechanism for safeguarding financial stability in the EU (European Stability Mechanism (EMS)). At the same time with the regard to extending debt crisis at a meeting of 21 July 2011 in Brussels, there was agreed the increasing flexibility of EFSF. This possibility can use states for borrowing the financial resources in the future only on the basis of "their prevention program".

\section{Summary}

From this, it is obvious that neither in national economic affairs, nor in economic relations inside the Union, there is no change (apart from the forced efforts to save money where is possible). Europe and its countries still remain by keeping old imagines, schemes and symbols at any price. It also documents the situation of August 2011 which again emphasis the need to transfer a number of decision-making powers to citizens, companies and countries, i.e., to social and economic institutions that are enforced their responsibility through their decision-making powers.

Without wishing to question the efforts of EU governments and the leadership of the Union as a whole, based on the development of practical state of the economy should be noted that many of these institutions deal with the topics and decide in cases which they can't influence by accountable way with regard to their competences and real knowledge.

After all, there is an example of the introduction of the euro, the efforts of a common monetary policy at the level of common institutions and the preservation of significant differences in fiscal policy also in those countries using the euro as a currency. 
Another relatively clear evidence of some counterproductive proposals, the measures and their compliance may be in the rule covering investment the technical provisions in bonds issued by central banks of EU countries. It should be as a priority and the surest investment opportunities. As a result of compliance this regulation insurers charge losses that may threaten their stability also in situations where the responsible manager of any insurance company is able to evaluate the risk of such investments.

The aim of this study was to assess some aspects of the functioning of states and EU institutions in terms of symmetry between their decision-making, competences and responsibilities based on the presented approaches solving current economic problems.

The analysis shows that the proportion between the decision and the responsible institutions within states and particularly in the European Union are far from optimal state and they are in many cases the main cause of existing economic problems. Looking ahead, it is necessary to consider positively the return of competences where can be held the responsibility by the implementation of decisions. The opposite approach can lead to enormous economic and then political consequences in the life of individual countries in Europe and worldwide.

\section{References}

Berne Union. (2009). Export, Publishing and Events Ltd. on behalf of the Berne Union, London. Retrieved from http://www.berneunion.org.uk/

Böhm, A. (2004). Ekonomika a řízení pojištoven v podmínkách po vstupu ČR do EU (Economy and running the insurance companies after accession Czech Republic to the EU).

Böhm, A., \& Fujerová, I. (2011). Collected volume from Liberec Economic Forum 2011. Development of Regulation and Decision-Making in the European Union.

Bydžovská, M. (2011). How many toxical assets are in the ECB? Retrieved from http://www.euroskop.cz/332/19270/clanek/kolik-je-v-ecb-toxickych-aktiv/

Česká Spořitelna a.s. (2006). Retrieved from http://www.csas.cz/banka/content/inet/internet/cs/Mesicnik_2006_02.pdf, 4

EU Statistics. (2010). Retrieved from http://www.epp.eurostat.ec.europa.eu/

Finacial Portal Finance. (2011). Retrieved from http://www.finance.cz

Kubátová, K. (2003). Daňová teorie a politika.

Larosière report. The high level group of financial supervision in the EU. (2009, February). Retrieved from http://ec.europa.eu/internal_market/finances/docs/de_larosiere_report_en.pdf

Prušvic, D. (2007). Interakce měnové a fiskální politiky v malé otevřené ekonomice v systému s autonomni měnovou politikou a fiskálním pravidlem. Retrieved from http://kvf.vse.cz/storage/1180482428_sb_prusvic.pdf

The Arrangement on Guidelines for Officially Supported Export Credits. (2011). Retrieved from http://www.oecd.org/officialdocuments/displaydocumentpdf?cote=tad/pg(2011)4\&doclanguage=en

The Statement of The Commission About the Rating Agencies (Sdělení Komise o ratingových agenturách 2006/C 59/02). (2006). Retrieved from http://eur-lex.europa.eu/LexUriServ/LexUriServ.do?uri=OJ:C:2006:059:0002:0006:CS:PDF

The Treaty on European Union (92/C 191/1). (2011). Retrieved from http://www.euroskop.cz 